\title{
ADSORPTION AND DEGRADATION BEHAVIOR OF METHANOL IN PRODUCED WATER IN THE SOILS OF NORTHERN SHAANXI GAS FIELD, CHINA
}

\author{
MA, Y. $.^{1,2^{*}}-\mathrm{LI}, \mathrm{Y}^{3}{ }^{3}-\mathrm{GAO}, \mathrm{L}^{3}-\mathrm{XIE}, \mathrm{J}^{4}$ \\ ${ }^{I}$ College of Petroleum Engineering, Shaanxi Province Key Laboratory of Advanced Stimulation \\ Technology for Oil \& Gas Reservoirs, Xi'an Shiyou University, Xi'an, Shaanxi 710065, China \\ (phone: +86-29-8838-2673; fax: +86-29-8823-4429) \\ ${ }^{2}$ Engineering Research Center of Development and Management for Low to Ultra-Low Permeability \\ Oil \& Gas Reservoirs in West China, Ministry of Education, Xi'an, Shaanxi 710065, China \\ (phone: +86-29-8838-2683; fax: +86-29-8823-4429) \\ ${ }^{3}$ No.2 Gas Production Plant, Changqing Oilfield Company, Yulin, Shaanxi 710200, China \\ (e-mail: lyao3_cq@petrochina.com.cn,gliang1_cq@petrochina.com.cn \\ phone:+86-29-8650-3011; fax: +86-29-8658-2076) \\ ${ }^{4}$ College of Chemistry and Chemical Engineering, Shaanxi Province Key Laboratory of Environment \\ Pollution Control Technology of Oil Gas and Reservior Protection, Xi'an Shiyou University, Xi'an, \\ Shaanxi 710065, P. R. China \\ (e-mail:Xie_juan@xsyu.edu.cn,1007724077@qq.com \\ phone: +86-29-8838-2706; fax: +86-29-8823-4429) \\ "Corresponding author \\ e-mail:mayun9401@xsyu.edu.cn \\ (Received $13^{\text {th }}$ Jul 2019; accepted $25^{\text {th }}$ Nov 2019)
}

\begin{abstract}
Injection of methanol as a thermodynamic inhibitor is a common approach in the petroleum industry. Due to the volatility and recovery process of methanol, it could be found in natural waters, sediments, soil, and so on. This study focused on adsorption and degradation behavior of methanol in produced water (PW) at northern Shaanxi oil and gas fields soil, China. Through dynamic tests, the results showed that the $\mathrm{pH}$, gas condensate, salinity of PW and temperature have weak influences on methanol adsorption on the soil. Through the simulated degradation experiments, the chemical oxidation, photo and thermal degradation were found not to be the main mechanism of methanol degradation (MD) in nature. The methanol in some soil could not de degraded completely by Nitrate-reducing bacteria (NRB) in the soil within 60 days unless methanol content was less than $600 \mathrm{mg} / \mathrm{L}$ with NRB medium. The Griess detection verified that there were NRB in five soils. Even without the NRB medium, there are great differences in MD of the soils. If the concentration of methanol was more than $1000 \mathrm{mg} / \mathrm{L}$, the MD efficiencies were obviously slowing down, nearly 0 . The longer the gas development time of the study region, the stronger the MD ability of the region's soil.
\end{abstract}

Keywords: methanol, adsorption, degradation, sandy soil, Nitrate-reducing bacteria (NRB)

\section{Introduction}

In economic and safety hazards points of view, it is crucial to avoid the formation of clathrate hydrate of gases in oil and natural gas transportation/production systems (Muromachi, 2019). Injection of methanol as a thermodynamic inhibitor is a common approach in industry to shift the hydrate phase boundary to higher pressures/lower temperatures. Because of its high volatility, methanol is lost in the vapor phase, which lead its toxicity to the environment and human beings (Aziz et al., 2002). Although methanol in aqueous solution was generally treated by biological treatment and advanced oxidation processes (AOPs), in which the most 
commonly used approaches were the up flow anaerobic sludge bed (UASB), supercritical water oxidation (SCWO), bio-filtration and plasma degradation (Ma et al., 2009, 2013; Fujii et al., 2011; Barcón et al., 2012; Zhen et al., 2017; Wu et al., 2019), but few studies focused on adsorption and degradation behavior of the methanol in produced water (PW) in the soil. The northern Shaanxi oil and gas fields is located in Ordos plateau (Semi-arid region), China. The surface layer of the soil is the quaternary aeolian sandy soil or brown desert soil, among which aeolian sandy soil is in the majority. Because of the special soil composition, the methanol will show special adsorption and degradation behavior in the soil. Through temperature oscillation dynamic tests and the simulated degradation of methanol in the five kinds of typical soil, the behavior of adsorption and degradation have been discussed, which lead to a better understanding of the influence of methanol on the north Shaanxi gas field environment.

\section{Material and Method}

\section{Soil Sample collection and pre-treatment}

The five kinds of soil samples were collected from five different sites located in Northern Shaanxi gas field, respectively is Jingbian gas field (1\#), Jingbian farmland (2\#), Zizhou gas field (3\#), Zizhou farmland (4\#) and Wuding river (5\#) in Mizhi county, Yunlin city. The map of study area were showed as in Fig. 1. The surface layer is the quaternary aeolian sandy soil or brown desert soil, among which aeolian sandy soil is in the majority (Ma et al., 2013). The sampling date was April to May, 2018. The sampling depth is $0 \sim 20 \mathrm{~cm}$. After the soil sample is naturally dried, ground and sifted with a $2 \mathrm{~mm}$ sifter, then stored in five bottles at low temperature.

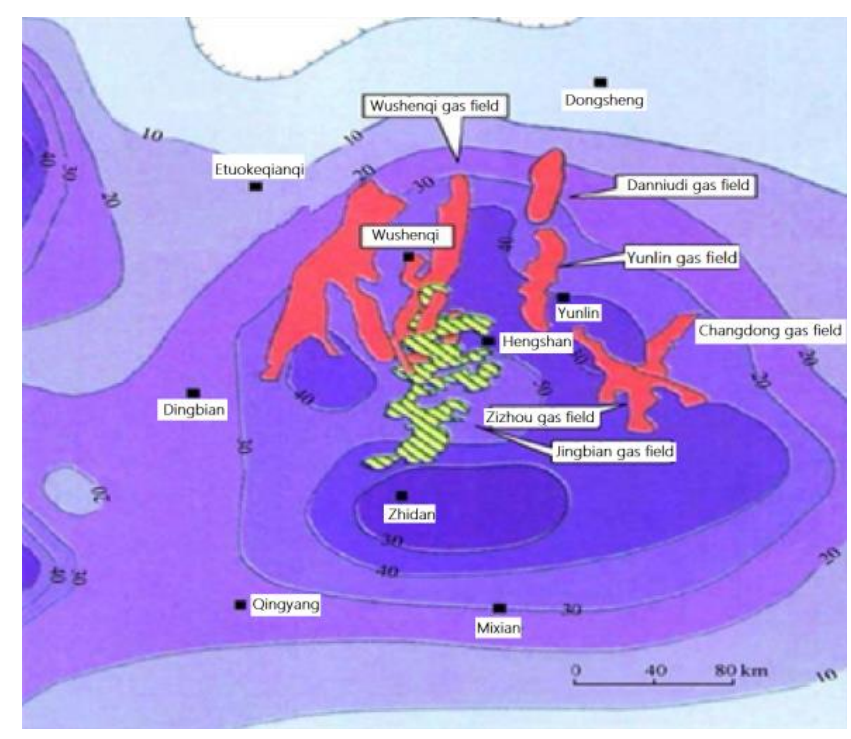

Figure 1. The map of study area

\section{Measurement of soil parameters}

The physiochemical analysis $(\mathrm{pH}$, moisture, organic matter content and mass size distribution) of five samples was respectively refer to "Soil dry matter and moisture determination - gravimetric method" (HJ 613-2011), "Soil test part II: determination of $\mathrm{pH}$ " (NY/T 1121.1 - 2006), "Determination of forest soil organic matter and calculation 
of carbon - nitrogen ratio" (LY/T 1237 - 1999) and the Wu's method (Ghasemy et al., 2019).

\section{Adsorption test}

\section{Adsorption of methanol in different soils}

Due to the strong adsorption capacity of bentonite and activated carbon, these two materials were selected as the experimental reference in order to facilitate the study of the adsorption capacity of methanol in five soil samples. The seven samples were taken respectively in the experiment and $20.00 \mathrm{~g}$ were put into a $250 \mathrm{~mL}$ glass bottle, and 100 $\mathrm{mL}$ methanol concentration of $1000 \mathrm{mg} / \mathrm{L}$ solution with $10000 \mathrm{mg} / \mathrm{L}$ salinity and a certain amount of microbial inhibitors were added. Then, the sealed $250 \mathrm{~mL}$ bottle were settled in the thermostatic oscillator (TS-200B, Shanghai Tiancheng co. LTD) under the condition of $25^{\circ} \mathrm{C}$ for $24 \mathrm{~h}$, later transferred to the soil suspension in the centrifuge tube at $4000 \mathrm{r} / \mathrm{min}$ centrifuge for $10 \mathrm{~min}$ after taking centrifugal supernatant on $2 \mathrm{~mL}$ for methanol concentration. The concentrations of methanol was determined by gas chromatography (Agilent HP 6890). A packed column (Agilent Porapak N G3591-80036) was used. The retention time of methanol was $5.652 \mathrm{~min}$ (Ma et al., 2013). The adsorption capacity and samples site were compared, and $3 \#$ was selected as the representative for future research.

\section{Adsorption equilibrium and isotherm of methanol in soil}

In Adsorption equilibrium test, the $2 \mathrm{~mL}$ supernatant was samples after $0.5,1,2,4,6$, $8,10,12,24 \mathrm{~h}$. In Adsorption isotherm test, the methanol concentration, respectively is $0,20,40,60,80,100,200,500$ and $1000 \mathrm{mg} / \mathrm{L}$. Other test conditions are consistent with conditions detailed above.

\section{Affecting factors of methanol adsorption in soil}

The range of $\mathrm{PW} \mathrm{pH}$, temperature, gas condensate, salinity were according to the quality of gas PW from Northern Shaanxi gas field (The quality of gas PW from North Shaanxi gas field had analyzed by our lab in the past 10 years). Other test conditions are consistent with conditions detailed above.

\section{Degradation behavior of Methanol in soils}

\section{Physicochemical factors on degradation of methanol in different simulation conditions}

When the gas PW with methanol is treated and injected back into the stratum, it will directly or indirectly enter the soil environment because of evaporation and leakage. According to the possible factors affecting degradation of methanol in the possible environment, ammonium persulfate and hydrogen peroxide (used as oil-field chemicals), high temperature and pressure (reinjection into some formations), strong ultraviolet (direct splar radiation) were selected to make a series of simulation experiments to study the degradation degree of methanol in gas PW under different conditions. A temperature and pressure reactor (Parr 4578, Parr instrument company, USA) was used to stimulate the condition of reinjection formation $\left(200^{\circ} \mathrm{C}\right.$ and $\left.15 \mathrm{MPa}\right)$. The $50 \mathrm{~g}$ core powder was added into the reactor, and the methanol equilibrium concentration after 12 hours adsorption in core powder was the baseline concentration for degradation. A UV light (80W, Xinbao Environmental Products Co., Ltd., CHN) was used to stimulate rapid splar 
radiation. The source of radiation was located $25 \mathrm{~cm}$ from samples and positioned horizontally. All solution is $1 \mathrm{~L}$ and $1000 \mathrm{mg} / \mathrm{L}$ methanol, and other experimental temperature is $25^{\circ} \mathrm{C}$ unless it is specifically requested.

\section{Stimulated degradation experiment in different soils}

Nitrate reducing bacteria (NRB) are very common in nature, most of which are facultative. When methanol $\left(\mathrm{CH}_{3} \mathrm{OH}\right)$ is used as the carbon source in wastewater treatment, the reaction formula for synthesis of exogenous denitrifying cells was shown in Eq.l (Ma and Wei, 2009).

$$
\mathrm{NO}_{3}^{-}+1.08 \mathrm{CH}_{3} \mathrm{OH}+0.24 \mathrm{H}_{2} \mathrm{CO}_{3} \rightarrow 0.06 \mathrm{C}_{5} \mathrm{H}_{7} \mathrm{NO}_{2}+0.47 \mathrm{~N}_{2}+1.68 \mathrm{H}_{2} \mathrm{O}+\mathrm{CO}_{2}+\mathrm{OH}^{-}
$$

According to the above theory, if methanol is degraded by NRB in nature, the degradation rate would increase. Therefore, the difference between with or without the medium of NRB ( $\mathrm{M}_{\mathrm{NRB}}$ ) was compared in different salinity water with different methanol concentration under $25^{\circ} \mathrm{C}$ and the proportion of $1 \#$ soil to methanol (20\%) after 60 days. Table 1 is the composition of $\mathrm{M}_{\mathrm{NRB}}$.

Table 1. The composition of $M_{N R B}$

\begin{tabular}{c|c|c|c|c|c|c|c|c}
\hline Composition & $\mathrm{KH}_{2} \mathrm{PO}_{4}$ & $\mathrm{KHCO}_{3}$ & $\mathrm{MgSO}_{4}$ & $\mathrm{FeCl}_{3}$ & $\mathrm{CaCl}_{2}$ & $\mathrm{CH}_{3} \mathrm{COONa}$ & $\left(\mathrm{NH}_{4}\right)_{2} \mathrm{SO}_{4}$ & $\mathrm{NaNO}_{3}$ \\
\hline Concentration (mg/L) & 30 & 500 & 200 & 100 & 30 & 860 & 660 & 850 \\
\hline
\end{tabular}

According above studies, the different soils was respectively soaked in the simulated water containing $200 \sim 2200 \mathrm{mg} / \mathrm{L}$ methanol (salinity: $100000 \mathrm{mg} / \mathrm{L}$ ) for $120 \mathrm{~d}$ with the proportion of the soils to methanol (20\%). In order to verify the effect of NRB, NRB was enriched, separated and screened form five soils samples, respectively. Two strains in every solid mediums plate were selected, which grow faster, colony moist, roundness, surface smooth, edge tidy, bulging and larger colonies. After many times of separation and purification, a strain was selected out of every two in the soil, which were 1S\#, 2S\#, 3S\#, 4S\# and 5S\# strain. The five strains of bacteria were tested with Griess reagent (García-Robledo et al., 2014).

Each experiment was performed three times, and the average value is calculated by three parallel experiments.

\section{Results and discussions}

\section{Physiochemical analysis results of five samples}

The physiochemical analysis results of five samples were shown in Table 2. The minimum moisture of five soils was $0.30 \%(\mathrm{w} / \mathrm{w})$ while the maximum is $1.45 \%(\mathrm{w} / \mathrm{w})$. The $\mathrm{pH}$ values of the tested soil samples were all around $8.0 \sim 9.0$, belonging to weakly alkaline soil. The organic content of the tested soil samples was also relatively small, among which the organic matter content of $4 \#$ was the highest, $0.655 \%(w / w)$ and that of $1 \#$ was the lowest, $0.266 \%(\mathrm{w} / \mathrm{w})$. All soils are sandy soil, except $4 \#$ soil is loam sandy soil, which would lead that it was easy for the methanol to infiltrate into the groundwater through them. 
Table 2. Physiochemical analysis results of five soil samples

\begin{tabular}{c|c|c|c|c|c|c|c|c|c}
\hline \multirow{2}{*}{ No. } & \multirow{2}{\text{pH}}{$\begin{array}{c}\text { Moisture } \\
(\mathbf{w} / \mathbf{w})\end{array}$} & $\begin{array}{c}\text { Organic matter } \\
(\mathbf{w} / \mathbf{w} \%)\end{array}$ & \multicolumn{5}{|c|}{ Mass size distribution (w/w\%) } & \multirow{2}{*}{ Type } \\
\cline { 5 - 8 } & & & $2-50 \mu \mathrm{m}$ & $50-100 \mu \mathrm{m}$ & $100-250 \mu \mathrm{m}$ & $250-1000 \mu \mathrm{m}$ & $1000-2000 \mu \mathrm{m}$ & \\
\hline 1\# & 8.34 & 0.30 & 0.266 & 0.0000 & 0.2413 & 0.7354 & 0.2330 & 0.0000 & sandy soil \\
$2 \#$ & 8.61 & 0.55 & 0.307 & 0.0000 & 0.1911 & 0.7616 & 0.4730 & 0.0000 & sandy soil \\
$3 \#$ & 8.78 & 1.10 & 0.410 & 0.0000 & 0.3149 & 0.4809 & 0.2042 & 0.0000 & sandy soil \\
$4 \#$ & 8.88 & 1.45 & 0.655 & 0.0000 & 0.5623 & 0.2014 & 0.2363 & 0.0000 & loam sandy soil \\
$5 \#$ & 8.66 & 0.50 & 0.366 & 0.0000 & 0.1659 & 0.7407 & 0.9340 & 0.0000 & sandy soil \\
\hline
\end{tabular}

\section{Adsorption of methanol in different soils}

The results of methanol adsorption capacity (MAC) in different soils are shown in Fig. 2. The MAC in the five tested soil samples was significantly different from that of activated carbon and bentonite. The largest adsorption capacity of activated carbon was up to $2.38 \mathrm{mg} / \mathrm{g}$, that of bentonite took second place, reached about $1.37 \mathrm{mg} / \mathrm{g}$, and those of five soils are between $0.45 \mathrm{mg} / \mathrm{g}$ and $0.60 \mathrm{mg} / \mathrm{g}$. Among five soils, the soil from Zizhou had higher adsorption capacity than those of other soils. The reasons should be that the soil from Zizhou has higher organic content which lead to higher adsorption capacity. The experimental results are consistent with the characteristics of small activated carbon/bentonite particles, large specific surface area of particles and large adsorption capacity. Therefore, it can be concluded that the five soils have a certain adsorption capacity for methanol, but the adsorption amount is relatively small. All that also should lead that most of methanol could infiltrate into groundwater through them easily and not be degraded in the soils.

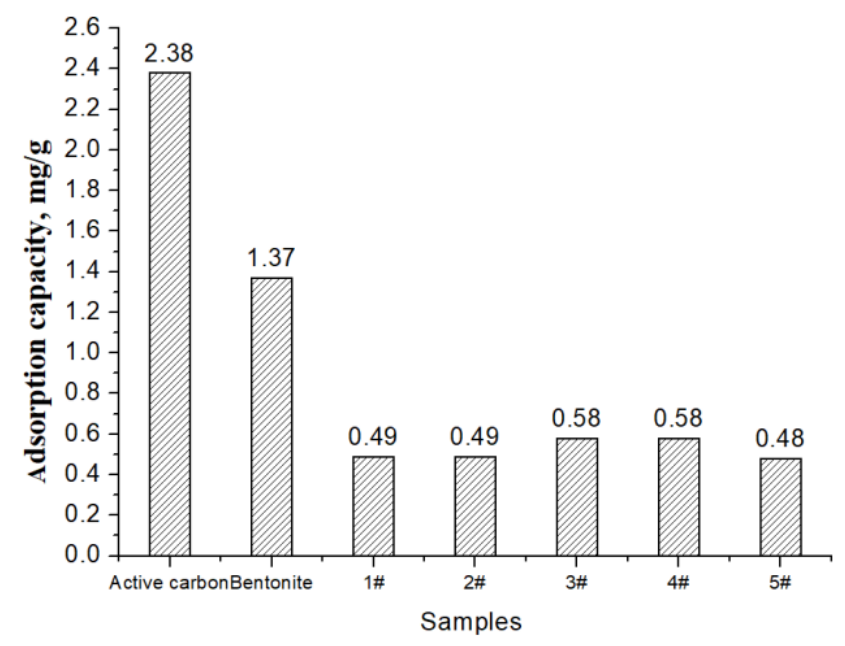

Figure 2. MAC in different samples and soils

\section{Adsorption equilibrium and isotherm of methanol in soil}

The adsorption equilibrium curve and isotherm curve of methanol in $3 \#$ soil respectively was shown in Fig. 3 and Fig. 4.

From Fig. 3, when the adsorption time was less than $10 \mathrm{~h}$, the adsorption capacity of methanol in the $3 \#$ soil increased rapidly, but when the adsorption time was more than 
$10 \mathrm{~h}$, the adsorption capacity tended to be stable, and the maximum adsorption amount was about $0.55 \mathrm{mg} / \mathrm{g}$. This reason is that the opportunity for the soil to fully contact methanol increases with the gradual extension of time, and the amount of methanol adsorption in the soil increases. From Fig. 4, when the methanol concentration is samller than $200 \mathrm{mg} / \mathrm{L}$, the adsorption capacity increases sharply with the increase of methanol concentration. When the methanol concentration is higher than $200 \mathrm{mg} / \mathrm{L}$, the adsorption capacity tends to be balanced, about $0.5 \mathrm{mg} / \mathrm{g}$, which indicated that the adsorption capacity of methanol in the soil had reached a saturated state.

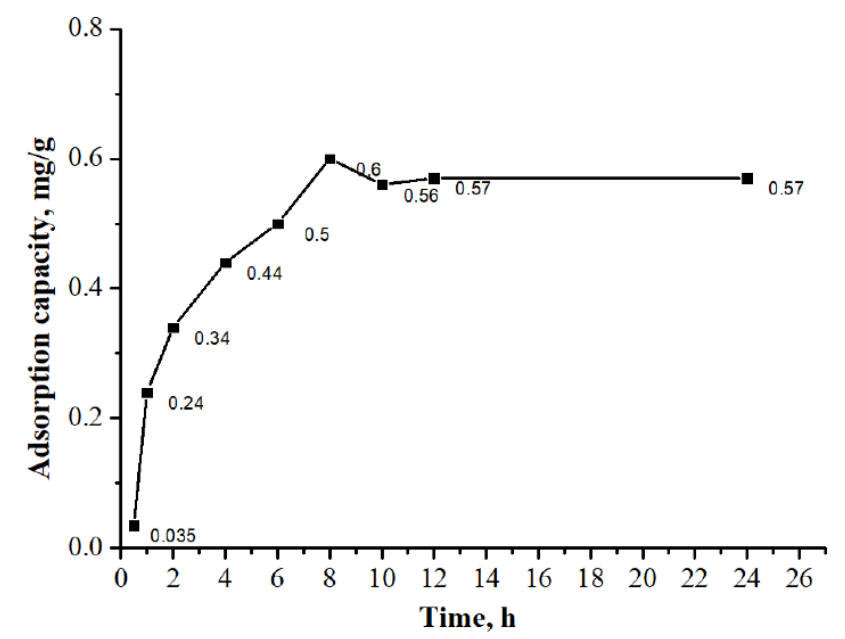

Figure 3. Adsorption equilibrium curve of methanol in 3\# soil

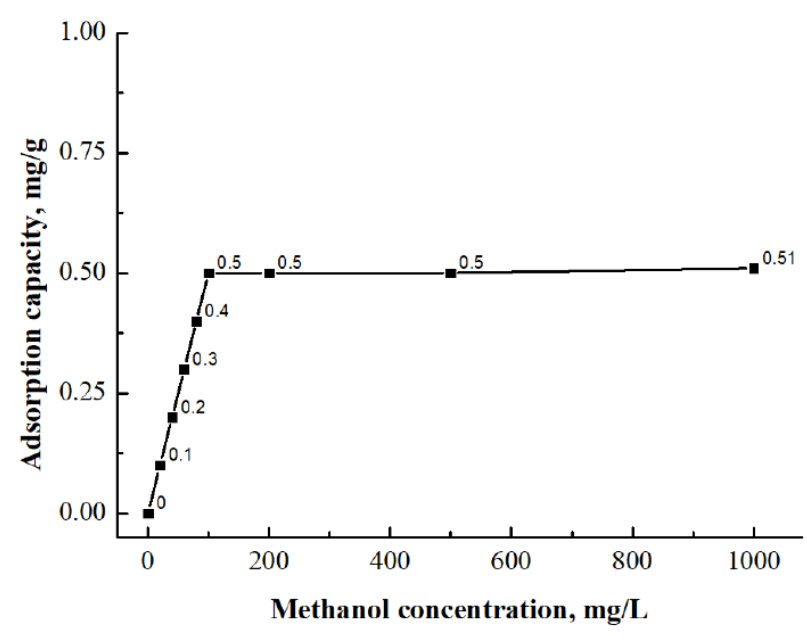

Figure 4. Isotherm curve of methanol in $3 \#$ soil

\section{Affecting factors of methanol adsorption in soil}

pH values

The influence of different $\mathrm{pH}$ values on the methanol adsorption amount (MAA) was shown in Fig. 5. As can be seen from Fig. 5, with the increase of $\mathrm{pH}$ value of solution, the MAAin soil gradually decreases from $0.458 \mathrm{mg} / \mathrm{g}$ to $0.007 \mathrm{mg} / \mathrm{g}$. In the alkaline environment, the sediments and organic matter in the soil may undergo flocculation 
changes, leading to the fact that methanol molecules cannot be uniformly adsorbed on the soil sediments and organic matter (Viotti et al., 2000). Lopez et al. (1996) believe that at low $\mathrm{pH}$, strong hydrogen bonds are formed between organic pollutants and $\mathrm{O}, \mathrm{N}$, and $\mathrm{H}$ atoms in some materials in the soil, but they are completely different under alkaline conditions, and the resistance to hydrogen bond formation increases, leading to hydrogen bond dissociation. Some scholars also reached the conclusion that the adsorption amount of an organic compound in alkaline soil was low, while that in acidic soil was high (Ertli and Marton, 2004; Goh and Lim, 2004). With the increase of $\mathrm{pH}$ value, the increase of $\mathrm{OH}^{-1}$ content on the surface of soil particles leads to the increase of electrostatic repulsion force, the decrease of charge density on the surface of soil, and the decrease of adsorption force on the surface of soil particles. The $\mathrm{pH}$ value is an important factor affecting the variable charge, and the change of $\mathrm{pH}$ value has an important impact on the electrostatic adsorption of anions. With the decrease of $\mathrm{pH}$ value, the positive charge increases, and the amount of electrostatic adsorption of anions increases. In the case of $\mathrm{pH}>7$, even the variable charge soil with kaolinite and iron and aluminum oxides as the main colloidal substances has a relatively low electrostatic adsorption capacity of anions (Zhang, 2009).

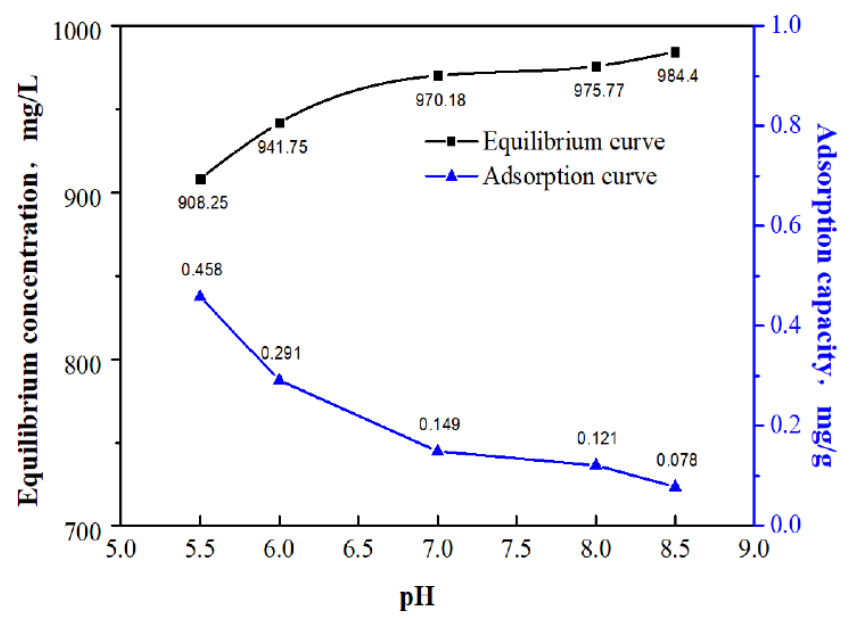

Figure 5. Influence of different $p H$ values on the MAA in 3\# soil

\section{Salinity}

The effects of water quality with different salinity on the adsorption of methanol in soil was shown in Fig. 6.

The MAA in soil increases from $0.373 \mathrm{mg} / \mathrm{g}$ to $0.487 \mathrm{mg} / \mathrm{g}$ with the increase of salinity in solution from $0 \mathrm{mg} / \mathrm{L}$ to $100000 \mathrm{mg} / \mathrm{L}$. This was due to the adsorption coefficient $(K p)$ is defined as follows Eq.2 (Pena et al., 2019):

$$
K_{p}=\frac{\text { Adsorption capacity of organic compounds in the solid phase, } \mathrm{mg} / \mathrm{g}}{\text { dissolved amount of organic matter in aqueous solution, } \mathrm{mg} / \mathrm{L}}
$$

From $E q .2$, the $K p$ is related to the adsorption amount in solid phase and the solubility of organic matter in water phase. With the increase of salinity in soil solution, the solubility of organic matter in water decreases, which is mainly due to the influence of "salting out". Salting out, in which salts are added to an aqueous solution of a substance, results in a decrease in the solubility of the substance. In this experiment, the soil adsorption increased with the increase 
of salinity, indicating that methanol was affected by "salting out". Since "salting out" reduced the value in the denominator of the above equation, $K p$ value increased (Zhao et al., 2000). The lower the solubility, the higher the solid adsorption. The adsorption capacity is closely related to the hydrophilicity of the adsorbed substance. Although salinity cannot change the nature of the adsorbed substance in the soil, it does change its solubility. Therefore, it is basically the same as increasing its hydrophobic effect, so the solid phase adsorption increases. It can be seen from the above analysis that the adsorption of pollutants by salinity mainly affects the solubility of pollutants (Gennadiev et al., 2015).

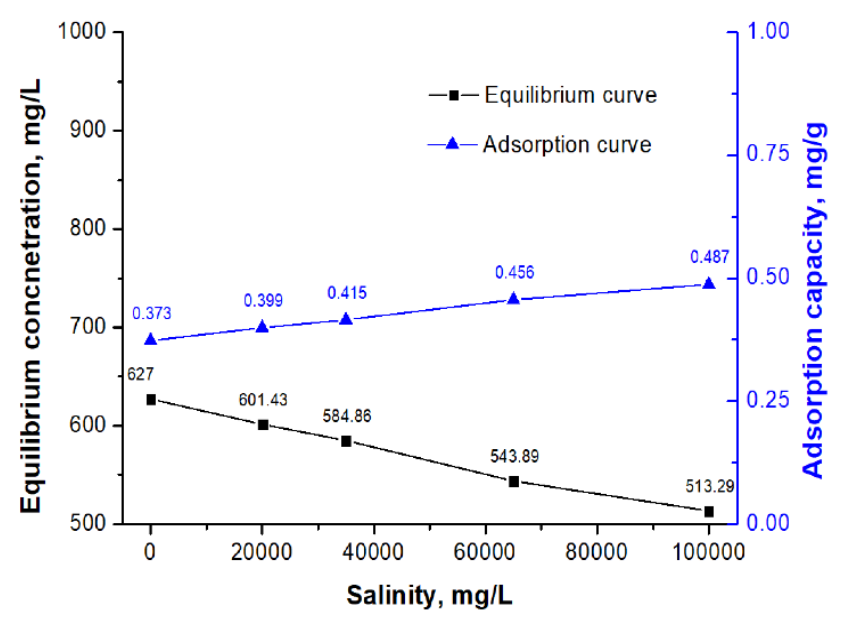

Figure 6. Influence of different salinity on the methanol adsorption amount in 3\# soil

\section{Condensate oil}

The effect of condensate oil content on the methanol adsorption in soil was shown in Fig. 7.

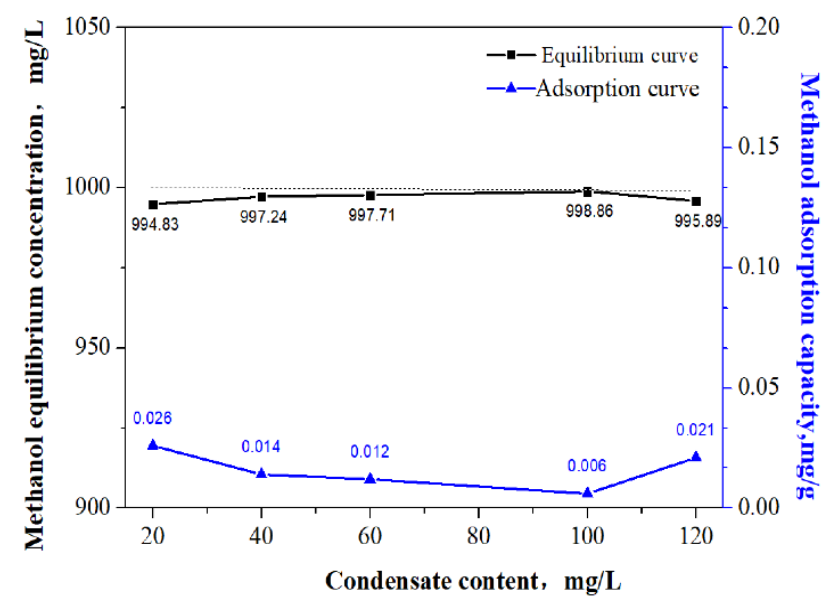

Figure 7. Effect of condensate oil content on the methanol adsorption in 3\# soil

With the increase of the condensate concentration, the equilibrium concentration of methanol in the soil did not change much, between $994.83 \mathrm{mg} / \mathrm{L}$ and $995.89 \mathrm{mg} / \mathrm{L}$, indicating that the condensate could not be adsorbed by the sediments or organic matters 
in the soil after entering the soil environment. Some scholars also found similar phenomena in soil-water system (Jonker et al., 2003, 2006). They called the minimum concentration of oil in sediments or soil in independent form as critical sperate phase concentration (CSPC), and pointed out that this concentration was related to organic matter content. Generally, the higher the organic matter content is, the higher the CSPC is, which is $11 \%$ (Khan et al., 2018) or $15 \%$ (Li et al., 2019) of the soil organic carbon content. The soil organic matter content of $3 \#$ sandy soil is $0.41 \%$, which should be 1100 or $1500 \mathrm{mg} / \mathrm{kg}$ according to the theoretical value of CSPC in previous studies. The practical significance of CSPC is that when the condensate oil concentration in the soil is greater than this value, the condensate oil can exist in the soil in the form of free state (independent phase), as a "adsorbent" to enhance the overall adsorption (distribution) ability of the soil to other organic pollutants. When the value is less than that, the condensate oil is absorbed by the soil organic matter in the form of "adsorbent", which may compete with other organic pollutants for the adsorption position on the organic matter. In the study of Jonker et al. $(2003,2006)$ this competitive adsorption was more obvious.

\section{Temperature}

The influence of environmental temperature on the MAA in the soil was shown in Fig. 8 . With the increase of temperature from $10^{\circ} \mathrm{C}$ to $35^{\circ} \mathrm{C}$, the MAA in the soil also increases obviously (from $0.330 \mathrm{mg} / \mathrm{g}$ to $0.975 \mathrm{mg} / \mathrm{g}$ ) when the temperature was below $35^{\circ} \mathrm{C}$. When the temperature rises to $35^{\circ} \mathrm{C}$, the adsorption curve begins to be smooth, methanol adsorption capacity is essentially unchanged. It indicates that the adsorption reaction rate of methanol in soil increases with the increase of temperature. When the adsorption capacity of methanol in soil reaches a balance, the MAA in soil does not increase, indicating that the adsorption of methanol in soil is an endothermic process. $\mathrm{Li}$ et al. (2019) believed that soil adsorption is a kind of biphasic adsorption, and mineral as a traditional solid adsorbent, organic matter as a distribution medium. As the temperature rises, water molecules are more affected by molecules than organics, and the relative adsorption competitiveness of organic matters increases, and the adsorption capacity on the mineral surface increases (Pena et al., 2019).

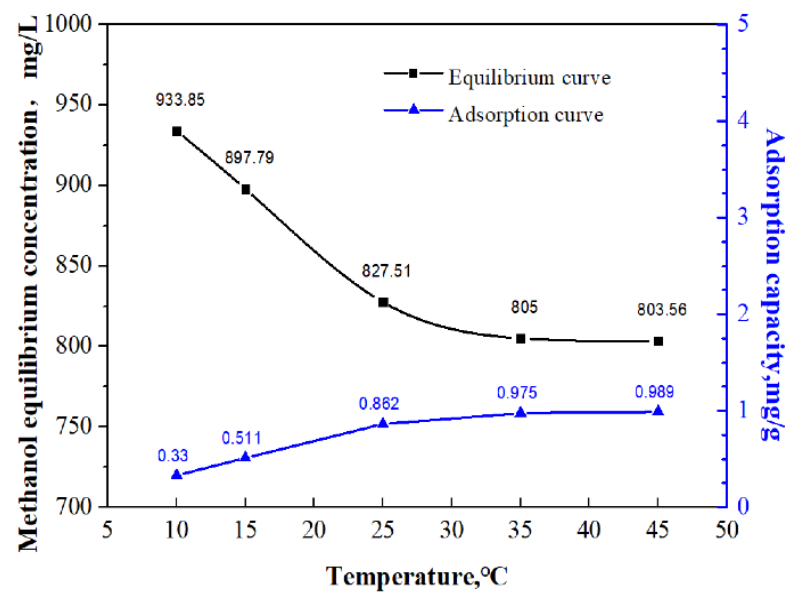

Figure 8. Influence of environmental temperature on the MAA in 3\# soil 


\section{Degradation behavior of methanol in soils}

\section{Physicochemical factors on degradation of methanol in different simulation conditions}

Degradation degree of methanol in different simulated extreme environment was shown in Table 3. The degradation efficiency $(\eta)$ of methanol in extreme environment $\left(200^{\circ} \mathrm{C}, 15 \mathrm{Mpa}\right)$ after 30 days was only $10.18 \%$. The $\eta$ of strong ultraviolet radiation and the chemical oxidation were $23.94 \%, 21.69 \%$ and $11.84 \%$, respectively. The radiation intensity and the concentration of chemical oxidant were usually more than their value in nature. The results showed that among the factors on degradation of organic matter in nature, the physicochemical factors, such as thermal degradation relying solely on temperature, chemical oxidation degradation and photo-degradation could not be found the main factors of methanol degradation (MD).

Table 3. Degradation degree of methanol in different simulated environment

\begin{tabular}{c|c|c|c|c|c|cc|c|c}
\hline $\begin{array}{c}\text { Simulated extreme environment } \\
\left(\mathbf{2 0 0}{ }^{\circ} \mathbf{C}, \mathbf{1 5} \text { MPa) }\right.\end{array}$ & \multicolumn{2}{c|}{$\begin{array}{c}\text { Strong ultraviolet radiation } \\
\text { (Power: 80W) }\end{array}$} & \multicolumn{3}{c}{$\begin{array}{c}\text { Chemical oxidation } \\
\text { (Reaction time: 30 min) }\end{array}$} \\
\hline $\begin{array}{c}\text { Reaction } \\
\text { time } \\
(\text { day) }\end{array}$ & $\begin{array}{c}\text { Concentration } \\
(\mathrm{mg} / \mathrm{L})\end{array}$ & $\begin{array}{c}\eta \\
(\%)\end{array}$ & $\begin{array}{c}\text { Reaction } \\
\text { time } \\
(\mathrm{h})\end{array}$ & $\begin{array}{c}\text { Concentration } \\
(\mathrm{mg} / \mathrm{L})\end{array}$ & $\begin{array}{c}\eta \\
(\%)\end{array}$ & $\begin{array}{c}\text { Reaction dosage } \\
(\mathrm{mg} / \mathrm{L})\end{array}$ & $\begin{array}{c}\text { Concentration } \\
(\mathrm{mg} / \mathrm{L})\end{array}$ & $\begin{array}{c}\eta \\
(\%)\end{array}$ \\
\hline 0 & 933 & 0 & 0 & 1000 & 0 & & 0 & 1000 & 0 \\
4 & 886 & 5.04 & 10 & 942 & 5.78 & Ammonium & 300 & 858 & 14.21 \\
6 & 861 & 7.72 & 20 & 901 & 9.86 & persulfate & 500 & 846 & 15.39 \\
8 & 859 & 7.93 & 40 & 827 & 17.31 & & 800 & 783 & 21.69 \\
\hline 10 & 857 & 8.15 & 60 & 803 & 19.72 & & 0 & 1000 & 0 \\
12 & 854 & 8.47 & 80 & 799 & 20.12 & Hydrogen & 5000 & 1093 & 2.51 \\
14 & 841 & 9.86 & 100 & 781 & 21.87 & $\begin{array}{c}\text { Peroxide } \\
\left(\mathrm{H}_{2} \mathrm{O}_{2}\right)\end{array}$ & 10000 & 1025 & 6.89 \\
30 & 838 & 10.18 & 120 & 761 & 23.94 & 20000 & 882 & 11.84 \\
\hline
\end{tabular}

\section{Nitrate reducing bacteria influence on methanol degradation}

NRB influence on (MD) in 1\# soil was shown in Fig. 9. Obviously, the ability to degrade methanol of $1 \#$ soil with $\mathrm{M}_{\mathrm{NRB}}$ was much higher than that of 1 \# soil without $\mathrm{M}_{\mathrm{NRB}}$, up more than $50 \%$, which indicated that NRB could significantly promoted the degradation methanol ability of the soil.

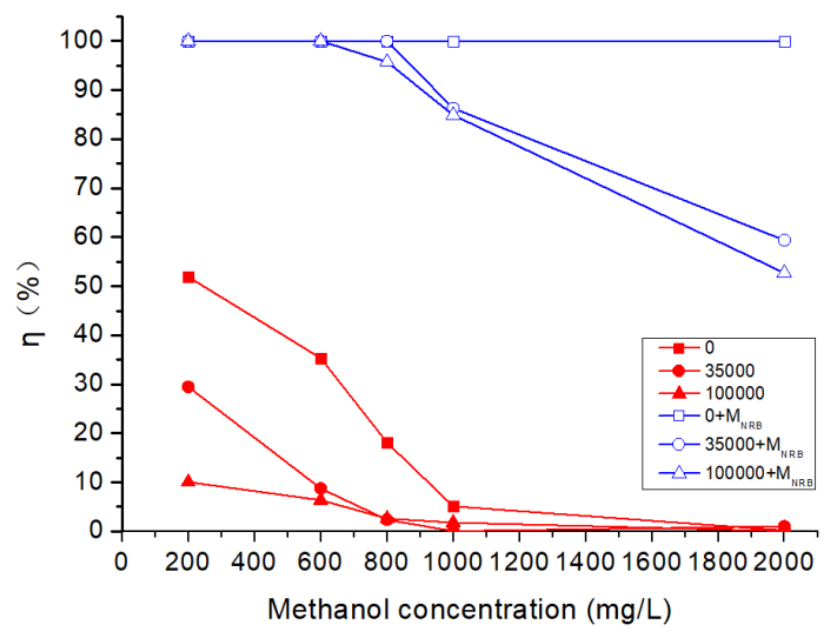

Figure 9. NRB influence on MD in 1\# soil (60 days) 
In the presence of $\mathrm{M}_{\mathrm{NRB}}$, methanol concentration in fresh water was less than $2000 \mathrm{mg} / \mathrm{L}$, the methanol can be completely degraded in 1\# soil. In the absence of $\mathrm{M}_{\mathrm{NRB}}$, methanol cannot be completely degraded within the range of $200 \sim 2000 \mathrm{mg} / \mathrm{L}$, the highest $\eta$ was only $51.9 \%$ and the lowest one was $0.07 \%$, nearly 0 . In the presence or absence of $\mathrm{M}_{\mathrm{NRB}}$, the degradation rate began to decline when the salinity increased, and the degradation rate decreased significantly when the methanol concentration was more than $1000 \mathrm{mg} / \mathrm{L}$. The reason should be that both salt and methanol have inhibitory effect on soil microorganisms and affect the biodegradation of methanol.

\section{Methanol degradation in different soils}

MD efficiency in different soils was shown in Fig. 10.

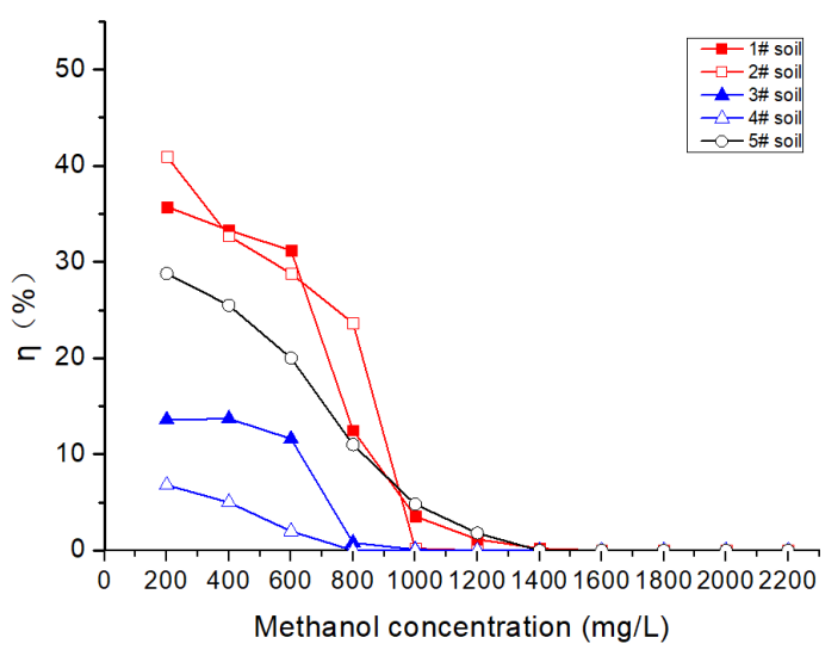

Figure 10. Different MD in different soils (Salinity: $100000 \mathrm{mg} / \mathrm{L}$, Without $M_{N R B}$ and 120 days)

When the salinity is $100000 \mathrm{mg} / \mathrm{L}$ in the absence of $\mathrm{M}_{\mathrm{NRB}}$, the degradation degree of methanol was obviously different when the initial concentrations were different. The highest $\eta$ was $2 \#$ soil, $41.0 \%$. The degradation rate decreased rapidly when the methanol concentration was greater than $1000 \mathrm{mg} / \mathrm{L}$. The lowest one was nearly 0 when the methanol concentration is more than $1400 \mathrm{mg} / \mathrm{L}$. There were great differences existing in degradation rate of different soil. The $1 \#$ and $2 \#$ soil from Jingbian had the best degradation ability of methanol, followed by the 5\# from the Wuding river, the worst were that of $3 \#$ and $4 \#$ soils from Zizhou. The main reasons should be the Jingbian region had the longest history of developing gas, so it is the earliest blocks where the methanol was first used among the three regions. The microbes in Jiangbian surrounding soil has more superiority strains capable of degrading methanol. The 5\# sediments was from Wuding river, so the microbial content in it was relatively high. Therefore, $3 \#$ soil and 4\# soil had the lower degradation ability of methanol than other's.

The Griess detection result of five strains was showed in Fig. 11. Compared with the control, all the bacterial solutions immediately changed from colorless or pale yellow to red after the addition of Griess reagent, which indicated that all strains were NRB. Under the same culture conditions, the color of the reaction between strain 3S\# and Griess reagent was lighter than that of other strains, while that of strains $1 \mathrm{~S} \#$ and $4 \mathrm{~S} \#$ was faster and darker. This may be related to the quantity of nitrate reductase and nitrite reductase 
produced by each strain. The higher the concentration of nitrate reductase and nitrite reductase in the bacterial solution, the deeper the color rendering, which indicated that the denitrification ability of each NRB is different (Ma and Wei, 2009). Compared with the degradation results, the denitrification ability of five NRB strains from five soils did not correspond to the MD capacity of five soils. The reason should be that the MD in the soil was not entirely dependent on NRB, but the NRB significantly promoted the degradation methanol ability of the soil.

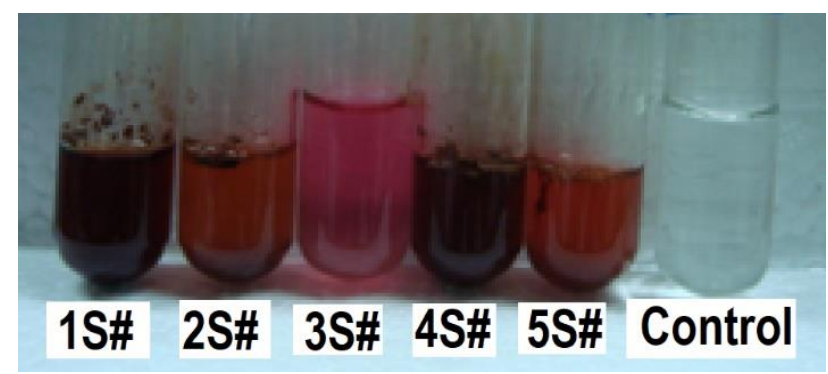

Figure 11. Griess detection photo of five strains form five soils

\section{Conclusion}

Five kinds of soils in the study region are sandy soil or loam sandy soil, and the MAA of them are relatively small, which would lead that the methanol to infiltrate into groundwater through them easily not be degraded in the soils. The $\mathrm{pH}$, gas condensate, salinity of PW, temperature have the weak influences on methanol adsorption on the soil. Through the simulated degradation experiment of methanol, the chemical oxidation degradation, photo-degradation and thermal degradation are not the main mechanism of MD. But when the methanol comes into contact with the soil, the methanol in some soils could not de degraded completely by NRB in the soil within 60 days unless methanol content is less than $600 \mathrm{mg} / \mathrm{L}$ with NRB medium. The NRB significantly promoted the degradation methanol ability of the soil. Even without the NRB medium, there are large differences among the soils although five soils had the certain capability to degrade methanol. When the methanol content increase or the salinity of the water increased without $\mathrm{M}_{\mathrm{NRB}}$, the MD rate decreased. The Griess detection verified the there were NRB in five soil. The longer the gas developing time of the studying region, the stronger the methanol degrading ability of the region's soil. If the concentration was more than $1000 \mathrm{mg} / \mathrm{L}$, the MD efficiencies were obviously slow after 120 days. Both salt and methanol have inhibitory effect on soil microorganisms and affect the biodegradation of methanol. The conclusion leaded to a better understanding of the influence of methanol on the north Shaanxi gas field environment, and suggested that the biodegradation of methanol in nature should be considered, especially NRB.

Funding. This research is supported by the Key laboratory Research Project of Shaanxi Education Department (CHN) under grant numbers 15JS090 and 17JS112.

Conflicts of Interests. The authors declare no conflict of interests. 


\section{REFERENCES}

[1] Aziz, M. H., Agrawal, A. K., Adhami, V. M., Ali, M. M., Baig, M. A., Seth, P. K. (2002): Methanol-induced neurotoxicity in pups exposed during lactation through mother: Role of folic acid. - Neurotoxicol. Teratol. 24(4): 519-527.

[2] Balseiro-Romero, M., Monterroso, C., Casares, J. J. (2018): Environmental Fate of Petroleum Hydrocarbons in Soil: Review of Multiphase Transport, Mass Transfer, and Natural Attenuation Processes. - Pedosphere 28(6): 833-847.

[3] Barcón, T., Alonso-Gutiérrez, J., Omil, F. (2012): Molecular and physiological approaches to understand the ecology of methanol degradation during the biofiltration of air streams. - Chemosphere 87: 1179-1185.

[4] Ertli, T., Marton, A., Földényi, R. (2004): Effect of pH and the role of organic matter in the adsorption of isoproturon on soils. - Chemosphere 57(8): 771-779.

[5] Fujii, T., Hayashi, R., Kawasaki, S., Suzuki, A., Oshima, Y. (2011): Water density effects on methanol oxidation in supercritical water at high pressure up to $100 \mathrm{MPa}$. - J. Supercrit. Fluids 58(1): 142-149.

[6] García-Robledo, E., Corzo, A., Papaspyrou, S. (2014): A fast and direct spectrophotometric method for the sequential determination of nitrate and nitrite at low concentrations in small volumes. - Marine Chemistry 162: 30-36.

[7] Gennadiev, A. N., Pikovskii, Yu. I., Tsibart, A. S., Smirnova, M. A. (2015): Hydrocarbons in Soils: Origin, Composition, and Behavior (Review). - Eurasian soil Sci. 48(10): 10761089.

[8] Ghasemy, A., Rahimi, E., Malekzadeh, A. (2019): Introduction of a new method for determining the particle-size distribution of fine-grained soils. - Measurement 132: 79-86.

[9] Goh, K. H., Lim, T. T. (2004): Geochemistry of inorganic arsenic and selenium in a tropical soil: effect of reaction time, $\mathrm{pH}$, and competitive anions on arsenic and selenium adsorption. - Chemosphere 55: 849-859.

[10] Jonker, M. T. O., Sinke, A. J. C., Brils, J. M., Koelmans, A. A. (2003): Sorption of Polycyclic aromatic hydrocarbons to oil contaminated sediment: Unresolved complex? Environmental Sci. Technol 37(22): 5197-5203.

[11] Jonker, M. T., Barendregt, A. (2006): Oil is a sedimentary supersorbent for polychlorinated binhenyls. - Environmental Sci. Technol. 40(12): 3829-3835.

[12] Khan, M. A. I., Biswas, B., Smith, E., Naidu, R., Megharaj, M. (2018): Toxicity assessment of fresh and weathered petroleum hydrocarbons in contaminated soil- a review. Chemosphere 212: 755-767.

[13] Li, M. F., Wang, L. J., Guo, D. (2019): Effect of land management practices on the concentration of dissolved organic matter in soil: A meta-analysis. - Geoderma 344: 74-81.

[14] Lopez, A., Mascolo, G., Földényi, R., Passino, R. (1996): Disinfection by-products formation during hypochlorination of isoproturon contaminated groundwater. - Water. Sci. Technol. 34: 351-358.

[15] Ma, F., Wei, L. (2009): Research on molecular ecology and activities regulation of oilfield sulfate reducing bacteria. - Science Press.

[16] Ma, R. S., Wang, L. F., Jiao, J. (2009): Treatment of high concentration methanol Wastewater by micro-electrolysis-catalytic oxidation Process. - Environ. Protect. Chem. Ind. 29: 51-53. (in Chinese).

[17] Ma, Y., Chen, J. R., Wu, X. M. (2013): Assessment of heavy metals contaminations from solidified waste drilling mud landfilling pond in Ordos plateau (Semi-arid region), China. - Environ. Eng. Manag. J. 12(9): 1837-1842.

[18] Ma, Y., Chen, J. R., Yang, B., Yu, Q. S. (2013): Degradation of high concentration methanol aqueous solution by dielectric barrier discharge. - IEEE T. Plasma Sci 41(7): 1716-1724.

[19] Maletic, S. P., Beljin, J. M., Roncevic, S. D., Grgic, M. G., Dalmacija, B. D. (2019): State of the art and future challenges for polycyclic aromatic hydrocarbons is sediments: sources, fate, bioavailability and remediation techniques. - J. Hazardous Materials 365(5): 467-482. 
[20] Muromachi, S. (2019): Phase equilibrium for clathrate hydrates formed in the (methane, carbon dioxide or ethane) + water + ammonium chloride system. - Fluid Phase Equilibria 485: 234-238.

[21] Pena, A., Delgado-Moreno, L., Rodríguez-Liébana, J. A. (2019): A review of the impact of wastewater on the fate of pesticides in soils: Effect of some soil and solution properties. Science of The Total Environment: 134468.

[22] Viotti, P., Petrangeli Papini, M., Chiulli, C. (2000): A laboratory experimental set-up for the study of organic compounds transport through unsaturated soils. - Waste Manag. Series 1: $525-532$.

[23] Wu, J., Liu, Q., Feng, B., Kong, Z., Jiang, B., Li, Y.-Y. (2019): Temperature effects on the methanogenesis enhancement and sulfidogenesis suppression in the UASB treatment of sulfate-rich methanol wastewater. - International Biodeterioration \& Biodegradation 142: 182-190.

[24] Zhang, B. G. (2009): Environmental chemistry. - Huazhong university of science and technology press: 204-205.

[25] Zhen, G. Y., Lu, X. Q., Kobayashi, T., Su, L. H., Kumar, G., Bakonyi, P., He, Y., Sivagurunathan, P., Nemestóthy, N., Xu, K., Zhao, Y. (2017): Continuous micro-current stimulation to upgrade methanolic wastewater biodegradation and biomethane recovery in an upflow anaerobic sludge blanket (UASB) reactor. - Chemosphere 180: 229-238. 